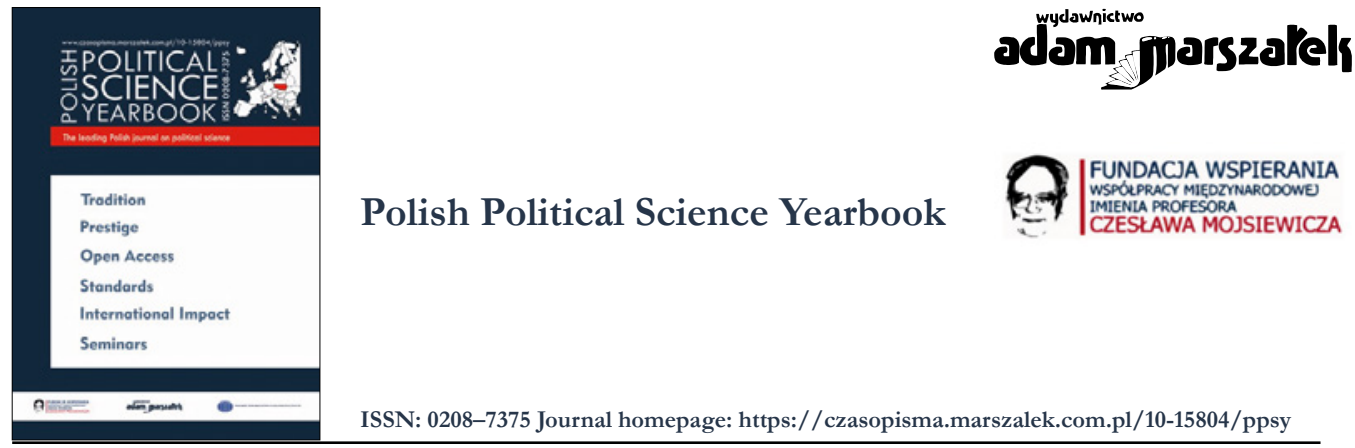

\title{
Conciliatory and Conflictual Ethnopolitical Concepts in the Republics of the Russian Federation: Tatarstan and Chechnya
}

\author{
Andrzej Wierzbicki ${ }^{a}$, Sylwia Gorlicka ${ }^{b}$ \\ ORCID: 0000-0002-5493-164X'a, 0000-0002-1205-030X
}

To cite this article please include the following information:

- Journal title: Polish Political Science Yearbook

- Volume number: 50

- Year of publication: 2021

- Published ahead-of-print

Example styles:

[APA Style]: Wierzbicki, A., Gorlicka, S. (2021). Conciliatory and Conflictual Ethnopolitical Concepts in the Republics of the Russian Federation: Tatarstan and Chechnya. Polish Political Science Yearbook, 50(4), pages. https://doi.org/10.15804/ppsy202157

[Chicago Style]: Andrzej Wierzbicki, Sylwia Gorlicka, "Conciliatory and Conflictual Ethnopolitical Concepts in the Republics of the Russian Federation: Tatarstan and Chechnya" Polish Political Science Yearbook 50, no. [4] (2021).

To link to this article: https://doi.org/10.15804/ppsy202157

Published ahead-of-print

Final submission: 9 March 2021

Published online: 17 December 2021

Printed issue: 2021

Submit your article to PPSY 


\title{
Andrzej Wierzbicki
}

University of Warsaw (Poland)

ORCID: 0000-0002-5493-164X

e-mail: awierzbicki@uw.edu.pl

\section{Sylwia Gorlicka}

University of Warsaw (Poland)

\section{Conciliatory and Conflictual Ethnopolitical Concepts in the Republics of the Russian Federation: Tatarstan and Chechnya}

\begin{abstract}
Russia is a state with a multi-ethnic federal structure inherited from the USSR. Implementing an ethnic policy that would unite and integrate its citizens is one of its most important goals. Among Russia’s federal subjects are also national republics pursuing their own ethno-political concepts, either conciliatory or conflictual. Tatarstan and Chechnya are examples of such republics. With the use of the comparative method, the article is an attempt at demonstrating many factors that have an impact on the shaping and implementing of the ethnic policy through such criteria as the status of the republics, the concept of the nation, and ethnocentrism, historical memory, the role of Islam and its politicization, and the language policy. The article also outlines their consequences and possible future scenarios.
\end{abstract}

Keywords: ethnopolitics, republic, Tatarstan, Chechnya, federal subject, Russia

\section{Introduction}

Contemporary Russia was created within the borders of the Russian Soviet Federative Socialist Republic and inherited the USSR's federal territorial and legal system, with the national republics among its federal subjects. The maintained federal structure resulted from the need to satisfy the state-forming aspirations of Russia's nations in the period of sovereignization at the turn of the 1980s and 1990s. Under ethnic federalism, an ethnos has the status of a titular nation in the political organism being the subject of the Russian 
Federation and enjoying the attributes of a national state. However, the Russian federalism is asymmetrical in favor of the republics, and it is a federation of national territories, which are not inhabited by the titular nations alone. The purpose of the federal ethnic is to shape and consolidate the all-Russian civic identity and the unity of the multi-ethnic nation of the Russian Federation (rossiı̌skoi natsii). At the same time, each federal subject may implement its own ethnopolitical strategy, which does not always reflect the goals set at the federal level. Tatarstan and Chechnya are good examples of such situations.

\section{Ethnopolitics}

The relatively extensive literature on this topic provides no precise or unambiguous definition of ethnopolitics. Ethnopolitics usually refers to a conflict where at least one party is a politically driven ethnic group striving to preserve, express, and develop its identity (Cordell \& Wollf, 2004, pp. 5-12). Monopolization of power by one of the ethnic/national creates favorable conditions for conflicts to arise. The source of such conflict may lie in the aspirations towards internal self-definition/self-determination, both at the cultural level in the form of national and cultural autonomy, as well as at the political level, in the form of national and territorial autonomy, or externally, by establishing a sovereign state, but also fighting for appropriate rights (relating to language, religion, culture), equal access to resources (power, prosperity, prestige) or for direct material and/or political support.

Many factors are conducive to an ethnopolitics based on conciliation, such as exhaustion from a protracted conflict, the interests of political elites, pressure, and incentives to compromise coming from the outside, e.g., from other states, as well as traditions and any compromise and cooperation precedents.

Joseph Rothschild, who was the first one to introduce the term ethnopolitics to the scientific literature, when systemizing the models according to specific state types, treated it as a synonym of such terms as the politicization of ethnicity, ethno-nationalism, ethnoregionalism, and ethno-secessionism, to analyze a situation in which social, cultural and economic interests, as well as claims, upheavals, and aspirations of ethnic groups, emerge in the national and international political arena (Rotschild, 1981, pp. 8-9).

Social elites - and not only the political elites but also the intellectual ones - play a key role in shaping and, later on, implementing an ethnic policy, as they act as the expert background for the parties to the compromise or the conflict. The role of the elites contributes to the politicization of ethnicity, the main ethno-political process, which Rothschild sees as serving four purposes: 1) showing the ethnic group that it may use politics to preserve its values and ethnic culture; 2) stimulating the group's interest in its own distinctiveness; 3) ethnic mobilization; 4) guiding the political behavior of an ethnic group (Rotschild, 1981, p. 6). Among these, ethnic mobilization plays a particularly vital role, understood as the building up of the group's cohesion and solidarity whereby the ethnic identity becomes superior to other types of identity, and contrasting from other communities. 
The identity of both the titular nation and the national/ethnic minority is also highly centered around the symbolic and emotional connection with the specific territory, shaping the concept of the group's origin and its historical memory. The ethnicity as such is in relation to politics usually understood through primordialism (Ben-Dior, 1988, p. 72), i.e., it is viewed through the features of a broad network of relatives, in which the symbols of its culture (language, religion, rituals, sometimes a common dwelling area) are the indicators of biological origin. However, the most important element is the faith in the shared origins, being more crucial than their actual existence. There is also a tendency which refers to the constructivist relation between ethnicity and politics, demonstrated in various contexts, e.g., in the public and private sphere, in the institutional sphere in the context of elections (attitudes of political parties and individuals) and outside the elections („behind the scenes” of official politics) (Chandra, 2012, pp. 12-13).

Given these considerations, including the difficulties in formulating an unambiguous and universal definition, for this article when referring to ethnopolitics, we will refer to the impact the power elites representing the state have on ethnic groups (minorities) whose social elites internally verify such impact from the perspective of their aim to preserve, express and develop their ethnicity, as well as mutual relations between the ethnic groups as such, leading to a compromise or, more often, a conflict due to opposing interests.

This article aims to verify the hypothesis that the ethnopolitics model promoted in Tatarstan, based on the compromise and conciliation, has proved to be more effective than the Chechen model since it has guaranteed the intra-ethnic peace in the republic and has earned it its special status of the federal subject of the Russian Federation. The Chechen model, on the other hand, has led to an armed conflict with the federal authorities, which at present - despite the head of the republic, Ramzan Kadyrov, being loyal to Moscow - strengthens the ethnocultural isolation of Chechnya from other federal subjects, especially those inhabited mainly by Russians which is unfavorable to the Chechens themselves, perceived as "foreigners" in the federal state.

The comparative analysis of the two models of ethnopolitics present in the federal subjects of the Russian Federation has already been adopted by Gulnaz Sharafutdinova, who has used the term "national inclusion” concerning Tatarstan and „ethnic exclusion” concerning Chechnya (Sharafutdinova, 2000, pp. 13-22), resulting in the demographic ethnicization of the republic (Table 1).

Numerous factors contributed to adopting a specific model of ethnopolitics in both republics. Firstly, the conditions were of a geopolitical/geographical nature. Tatarstan is located in the Volga region in the center of Russia, with no external borders. On the other hand, Chechnya is a republic in the North Caucasus, bordering Georgia. Their geographical location is linked to cultural and historical conditions. The area of the Republic of Tatarstan became part of the Russian state in the second half of the $16^{\text {th }} \mathrm{c}$. Thus, for several hundreds of years, the area witnessed the merging of the Byzantine and Islam civilizations, the cultures of Slavs, Russians, Tatars, Turks, and the Finno-Ugric people. It formed a Euro-Asian ethnic, 
Table 1. Ethnic structure of Tatarstan and Chechnya in years 1989*_2010

\begin{tabular}{lll}
\hline Year & Tatarstan & Chechnya $^{* *}$ \\
\hline 1989 & Tatars 48.5\%, Russians 43.2\%, Chuvash people & $\begin{array}{l}\text { Chechens 57.8\%; Russians 23.1; Ingush } \\
\text { people 12.9; Armenians 1.2 }\end{array}$ \\
\hline $3.7 \%$ & Tatars 53.2, Russians 39.6\%, Chuvash people 3.1 & $\begin{array}{l}\text { Chechens 95\%; Russians 1.9\%, Kumyks 1\%; } \\
\text { Ingush people 0.1 }\end{array}$ \\
\hline 2010 & &
\end{tabular}

* The last census taken in the USSR; ${ }^{* *}$ Chechen-Ingush Autonomic Soviet Socialist Republic.

Source: Vsesoiuznaia perepis' naseleniia 1989 goda. Natsionalnyĭ sostav naseleniia po regionam Rossii. http:// www.demoscope.ru/weekly/ssp/rus_nac89.php?reg=42,49; Vsesoiuznaia perepis' naseleniia 2010 goda. Naselenie po natsional'nosti, polu i sub" ektam Rossiǔskoŭ Federatsii. http://www.demoscope.ru/weekly/ssp/rus_etn_10. php?reg $=42,47$

cultural, and religious fusion. On the other hand, Chechnya became part of the Russian Empire three hundred years later and is, in addition, separated from the rest of the country by a natural border, which only adds to the isolation and limited contact with other nations and their cultures. The lingering mutual stereotypes of Russians and Chechens, as the inhabitants of the North Caucasus (Osobennosti kavkazskogo mentaliteta i "novaia Rossiia", $2011)^{1}$, do not help either.

The economic factor is also of great importance. Tatarstan, having a more varied and developed economic infrastructure, was at the beginning of the 1990s closely connected with the federal economy, while Chechnya's dependence on the federal economy was to a large extent weaker, and the republic's authorities wanted to secure exclusive rights to extract crude oil on its territory. In the end, the personal factor proved to be decisive. Tatarstan was at that time headed by Mintimer Shaimiev, an experienced yet capable of compromise apparatchik, while the president of Chechnya, Dzhokhar Dudayev, was a radical general of the Soviet Army and hostile towards Russians.

The comparative analysis of the two models of ethnopolitics will be made based on the legal and political status that these republics have in Russia's federal system, their attitude towards historical memory, regarding own statehood, the concept of the nation and ethnocratism, the role of Islam and its politicization, and the language policy.

1 Russians and inhabitants of the North Caucasus perceive each other as persons of a lesser social status. Russians refer to the inhabitants of the Caucasus as "persons of Caucasian nationality", a term used pejoratively. On the other hand, it is noteworthy to consider how the inhabitants of the Caucasus see Russians: "According to the inhabitants of the Caucasus, Russians, living outside the system of clan relations, are treated as persons of a lesser social status, «extras», and Russia is to them an "area of criminal expansion, without the traditional standards and restrictions observed in the national republics". 


\section{Federalism and the Status of Republics}

Article 1 of the Constitution of the Republic of Tatarstan (RT) stipulates that "the Republic of Tatarstan is a democratic state governed by the rule of law, united with the Russian Federation" and as the subject of the Russian Federation, it has a specified scope of sovereignty as a republic ${ }^{2}$ and the right to maintain its international political and economic relations. The source of the republic's status is the Constitution of the Russian Federation (RF) and the bilateral agreements (Konstitutsiia Respubliki Tatarstan, 2003) ${ }^{3}$. Tatarstan aspired for as complete sovereignty as possible, and the republic adopted its own model of relations with the federal authorities, based on extensive self-reliance and independence. The source of this model of sovereignty and Tatar relations with the federal authorities lies undoubtedly in the fact that the Tatars were among the few nations in Russia to have had their statehood in the past.

In Tatarstan, similarly as in other Russian republics, there are at least two approaches towards the republic's status, the idea of statehood and the pursued model of ethnopolitics the negotiation-based (conciliatory) one and the conflictual (radical) one (Wierzbicki, 2011, p. 161). The Tatarstan authorities have adopted the first one. They assumed that sovereignty - understood as a specified, high level of the republic's political and economic self-reliance within the Russian Federation - should not be equated with separatism. Supporting the idea of Tatarstan being part of the Russian Federation, they saw the federal structure of Russia as the only possible guarantee of survival for the Tatar nation. The reasons behind such a stance may be various and often interrelated. The president of Tatarstan, M. Shaimiev, enjoyed strong support from the federal authorities, including Vladimir Putin. According to Rem Latypov: "By using, at the onset of his presidency, the few but boisterous radical Tatar nationalists to intimidate the federal authorities, the cunning fox of Shaimiev did not forget to threaten the Kremlin with the » specter of separatism « also at a later stage, as if there was a conditional, deep-hidden wish lingering in the Tatar nation to set themselves free of Russia and Russians, and to create a sovereign national state. For Shaimiev, playing the "independence card « has always been merely a tactical move, the higher aim being the consolidation of the power system of ethno-nomenclature inherited from the Soviet times" (Latypov, 2009).

The substantial concessions granted by the federal authorities were the price paid to the Tatar pro-Soviet elites who were seen as a guarantee of Tatarstan remaining one of the

2 This concerns full state authority in relation to matters outside the competence reserved for the Russian Federation and delegation of authority between the Russian Federation and Republic of Tatarstan.

3 Konstitutsiia Respubliki Tatarstan (v redaktsii zakonov Respubliki Tatarstan ot 19 aprelia 2002 goda № 1380, ot 15 sentiabria 2003 goda № 34-3RT, ot 12 marta 2004 goda № 10-3RT, ot 14 marta 2005 goda № 55-3RT, ot 30 marta 2010 goda № 10-3RT, ot 22 noiabria 2010 goda № 79-3RT, ot 22 iiunia 2012 goda № 40-3RT), 3 January 2020. http://minjust.tatarstan.ru/rus/konstitutsiya.htm?pub_id=1084014.htm 
subjects of the Russian Federation. In this way, the president of Tatarstan and his apparatus managed to neutralize the nationalist opposition by representing the conflict-centered approach and demanding complete independence. As underlined by Christopher Williams, it was the political experience of Shaimiev, which he had gained in the Soviet apparatus, and his negotiation skills that enabled Tatarstan to avoid the ethnopolitical conflict with the federal authorities. Shaimiev, on the one hand, supported political unity with Russia, and on the other, he advocated equal status and treatment and the right to self-determination within the federation and to secure Tatarstan's economic basis.

As a result, in the referendum held on March 22, 1992, over 60\% voted for independence, including nearly half of Russians residing in the republic. On March 31, 1992, Tatarstan did not sign the Treaty on delimitation of jurisdictional subjects and plenary powers between the state bodies of the Russian Federation and the state bodies of sovereign republics in the Russian Federation. Instead, it signed a separate bilateral agreement with the federal authorities in February 1994, On delimitation of jurisdictional subjects and mutual delegation of authority between the state bodies of the Russian Federation and the state bodies of the Republic of Tatarstan, renewed in 2007 for ten years ${ }^{4}$.

Chechnya proved to be a particular case as regards Russian federalism since it had favorable conditions for the most extreme form of autonomy - secession: its geographical location on the border of the Russian territory, alongside its immense geopolitical potential, its history, demographic majority of the titular nation over Russians, Islam being a religion conducive to separatist tendencies, the presence of a weapon ${ }^{5}$, relations between the federal and the Chechen elites, and the raw material resources. These factors were also effectively used by the external parties since the political climate in Russia was a convenient ground for external interventions $s^{6}$, which was not without impact on both Russian-Chechen wars.

It is believed that Chechen separatism in its strict sense began with the first Chechen National Congress at the end of 1990 when the sovereign Chechen state was proclaimed. The peace treaty and principles of inter-relation between the Russian Federation and the Chechen Republic of Ichkeria signed on May 12, 1997, was, in fact, the termination of the federal relationship. Through such agreements, the republics tried to gain more benefits in the form of tax reliefs, privatization, and recruitment of employees to the regional structures of the federal bodies.

However, the growing ideological and political split among the Chechen elites, together with the change of power in Moscow, and Vladimir Putin's (Wolosky, 2000) ensuing fight against the influence of the Russian oligarchs and the Chechen separatists' leaders, who benefitted from the war financially, brought the conflict to an end. To a large extent, it was

4 Now not in force as it was not extended after the expiry date.

5 Left behind in Chechnya by the Russian troops in 1991.

6 Western countries and the broadly understood Islamic world. A more thorough analysis of this issue is beyond the topic of this paper. 
a result of the agreement between the federal government and the Sufi elites in Chechnya (including the Kadyrov clan), which secured Moscow's support in exchange for the stabilization in the region the republic formally remaining part of the Russian Federation. In order to strengthen the potential of the region, in 2010, the North Caucasian Federal District was created for the integrated social and economic development of the North Caucasus.

\section{Historical Memory}

What strengthens the Tatar national identity is the historical memory of its long-lost statehood and the belief that Tatars hold a special position among Russia's Turkish-speaking and Muslim nations ${ }^{7}$. The memory of the lost statehood remained among Tatars throughout the entire period of the Russian rule, having its culmination at the turn of the $19^{\text {th }}$ and $20^{\text {th }}$ century, in the form of the plans for a national and cultural, as well as a national and territorial autonomy ${ }^{8}$. In their tradition of the state-formation process, the Volga Tatars invoke the following two state organisms - Volga Bulgaria ${ }^{9}$, created in the $10^{\text {th }}$ century, and the Khanate of Kazan, formed after the disintegration of the Golden Horde, with the latter seen as the more significant one.

Some historians underline that the Grand Duchy of Moscow and the Khanate of Kazan shared the same vision of integrating the Eurasian territories. As we know, this vision was eventually fulfilled by Moscow, however, with the Tatar contribution, represented by the Khanate of Kazan (Galperin, 2000; Trepavlov, 2003). Thus, there appeared even attempts at the reinterpretation of the history of Russia, against the principle to see the history of Russia as mainly the history of Orthodox Russians. It was put most clearly by Rafael Hakimov,

7 In the past, Tatars lost their original ethnic territory and the density of settlement. Even in the Republic of Tatarstan they account for only slightly more than half of the population. They inhabit a large area covering the Volga Region, areas near the Kama River, the Ural Mountains and Siberia.

8 These projects were to be synthesised in the creation of the Idel-Ural Republic, which would encompass the areas of the Central Volga Region and the Urals, inhabited by Turkic and Finno-Ugric peoples, i.e., the present Tatarstan, Bashkortostan, Chuvashia, the Mari El Republic and the neighbouring areas. This plan was almost implemented after the February Revolution, but after the October Revolution, the Bolsheviks firmly rejected this project. As an alternative, attempts were made to create a Tatar-Bashkir Soviet Republic, but eventually two separate autonomous republics were formed. Thus, the Tatars, though having a tradition of their own statehood, had to settle for the status of an autonomous republic, because according to the principles of creating union republics, adopted in the 1930s, the Tatar ASSR had no external borders with the USSR.

9 At the beginning of the 20th century, a section of the Tatar movement, referring to the traditions of Volga Bulgaria and trying to instil the ethnonym of Bulgar among the Tatar population, revived in Kazan. However, this view did not gain wider support from the Tatar intelligentsia due to the fear that limiting the national history to the traditions of Volga Bulgaria would deprive the Volga Tatars of their ethnocultural ties with Siberian or Crimean Tatars. 
a historian from Tatarstan, who undermines the meaning of the official Russian historical narrative, according to which, Kyiv (Kievan Rus), located outside the present borders of Russia, is considered its cradle (Hakimov, 2005).

After the conquest of the Khanate of Kazan by Ivan the Terrible in 1552, this area became the largest religious and cultural Muslim center in the European part of Russia. Furthermore, the Tatars had a special place in Russia's policy towards the Turkic and Muslim nations. The influence of the Tatars in Russia is demonstrated by the multi-ethnic origin of the Russian political and intellectual elites. Therefore, it is believed that Tatars are the leading nation in the Tatar and Islamic world, co-existing alongside the Russian Orthodox world (Hakim, 2003, p. 35) ${ }^{10}$.

According to the Tatar intellectual elites, representing a moderate nationalism, the Republic of Tatarstan is the continuation of the Tatar state - a symbol of the "Golden Age" in the development of the Tatar nation - which they lost in 1552. In this version of historical memory, the fall of Kazan had negatively affected the material and spiritual culture of the Tatar nation, also leading to its forced Christianization. However, the mass perception of the Kazan Khanate is not that unambiguous (Karbainov, 2018, pp. 225-227) ${ }^{11}$. The inhabitants of Tatarstan are more focused on the current developments and processes than on the events from the distant past. Moreover, the republic's version of history is overshadowed by the all-Russian version, the attitude towards the Second World War being one example (Karbainov, 2018, pp. 229-230).

The historical memory of Chechens dates back only as far as the $19^{\text {th }}$ century. Their divided internal structure, including the tribal units ${ }^{12}$ and the rivalry between them, was not conducive to building an independent state and consolidating the nation. However, the fact that already in the $15^{\text {th }}$ century, the Chechens had their power structure is put forward as an argument in favor of the Republic of Chechnya becoming independent of the Russian Federation.

10 There appear, therefore, some Tatar-centric suggestions to make Kazan, the capital of Tatarstan, a second informal capital city of Russia, as Moscow is not able to perform the capital functions for Russian Tatars (not only from Tatarstan.

11 According to a survey conducted in May 2014, most Tatar respondents (17.2\%) considered the modern period to be the "Golden age" in the history of Tatarstan, and 15.8\% - the Kazan Khanate. The events which make Tatars most proud of the history of Tatarstan are the victory in the Great Patriotic War (28.7\%) and the organization of the World University Games in Kazan in 2013 (27.7\%). The Great Patriotic War (1941-1945) is also considered to be the most tragic event in the history of Tatarstan (32.3\%). Volga Bulgaria enjoys the greatest interest (40.0\%).

12 The basic unit of the Chechen socio-political organization was the dözal, a family that was part of a lineage ( $c^{\prime}$ ina nach), and these could form larger units teip, which could also be a kind of territorial community consisting of one or more villages. 
At present, the most important event in the historical memory of Chechens is the Caucasian War (1817-1864), and its central figure is one of the leaders of Caucasian resistance Imam Shamil, who managed to build a centralized, theocratic state (Chuev, 2004) ${ }^{13}$.

Another important event in the historical memory of the Chechen nation is the repressions against the local religious elites in the 1920s, including removing the Chechens from the personnel of state offices ${ }^{14}$. The traditional Caucasian social structures were eliminated, and the Soviet-modelled ones were created in their place.

A dramatic event in the history of the Chechen nation was also their deportation to Central Asia in the 1940s, a form of collective punishment for their alleged collaboration with the Germans during the Second World War (Avioutskii, 2005; Gdański, 2005) ${ }^{15}$. Unfortunately, during these events, their material culture was destroyed, which undoubtedly resulted in our limited knowledge of the history of the Vainakh people ${ }^{16}$.

In 1956, after the death of Stalin and the Secret Speech of Khrushchev during the $20^{\text {th }}$ Party Congress, the supervision of the Chechen internal institutions was lifted, which, however, was not followed by the return of their confiscated property. The Chechen population also took it hard when it became forbidden to settle in the mountainous regions (Grochmalski, 1999, p. 281). Mountains had always been their refuge.

To describe the strategy of ethnopolitics implemented in a given country, it is essential to adopt a specific concept of the nation.

\section{The Concepts of a Nation and Ethnocratism}

At the beginning of the $20^{\text {th }}$ century, there were two visible concepts of a nation in the ethnic policy implemented in Tatarstan. The republic's authorities advocate the first one, and it takes into account the polyethnic structure of the republic's population (with around half of the inhabitants not being of Tatar origin), as well as the historical and cultural background. Its cornerstone is the Tatarstan, republican identity, rooted in shared citizenship, shared settlement, and social, economic, spiritual, and cultural ties between the inhabitants of Tatarstan,

13 One of the more interesting examples is the weekly newspaper 'Gazawat' published in 1943-1944. Its editorial team was established along with the North Caucasus National Committee based in Berlin, controlled by the Wartime Propaganda Division. The articles were anti-Soviet and referred to the North Caucasian nineteenth-century national liberation traditions and Imam Shamil. It was published in Russian as well as in Chechen, among other languages.

14 There was not a single Chechen leader at the head of the Republic before 1988.

15 This question remains largely unexplained to this day.

16 The significance of this subject in the contemporary historical discussion in Russia can also be seen in the film from 2014 directed by Hussein Erkenov, entitled „Prikazano zabyt”, dedicated to the memory of the victims of those tragic events. The film's climax scene is when a barn into which the NKVD officers had driven the residents of the village of Chaibach, as it was too difficult to transport them to Kazakhstan, is set on fire. 
reinforced by their shared past, regardless of their nationality. The strongest ethno-cultural component of this concept is Tatars as the titular nation of the republic. By referring to the Russian sentiments, present also in other post-Soviet states, the ruling elite has partly taken over the Tatar nationalists' agenda to marginalize this group and stay in power. The concept of the Tatarstan civic nation is constructed by the republican and predominately Tatar ruling elite, shaped in the USSR and having almost mono-ethnic control over the state institutions. The non-Tatar inhabitants of the republic believe that the authorities in this manner promote the concept of an ethnic nation. The Tatar ruling elites, led by the first president of Tatarstan Mintimer Shaimiev ${ }^{17}$ and his successor Rustam Minnikhanov, enjoy the support of the federal authorities since they guarantee Tatarstan being part of the Russian Federation and an ethnopolitics that ensures social stabilization, ethnic peace, and stable economic development in the Volga Region, as opposed to the North Caucasus.

This model of the Tatarstan nation also relies on the republic's geopolitical location and refers to Eurasianism. The speeches of $\mathrm{M}$. Shaimiev and the initiatives pursued by the highest authorities are directed towards a consolidated image of Tatarstan as a Eurasian republic (Model Tatarstana, 2000).

The aim of solidifying the concept of the Tatarstan nation is to ensure a comprehensive development for the Tatar nation and the republic of Tatarstan as a historically shaped form of Tatar statehood and to guarantee equal conditions for development to representatives of all nations that form the multi-ethnic nation of the republic. Apart from the Tatars, this concerns mainly Russians and followers of the Orthodox $\mathrm{Church}^{18}$. It helped prevent the mass migration of Russians and maintain a stable demographic structure in the republic. The successful implementation of the conciliatory model of ethnopolitics in Tatarstan owes much also to the stable social and political situation and a high level of economic development. The republic is among a few subjects of the Russian Federation that contribute to the federal budget. Compared to other subjects, it also ensures high living standards and a good social and transport infrastructure.

The shaping of the Tatarstan identity is a republican reflection of the all-Russian concept of a civic nation (rossiǔskol natsii). According to the research made in years 2016-2017, the idea formulated as "Tatarstan - a territory of inter-ethnic and inter-religion communication,

17 He was, among other things, the Minister of Land Reclamation and Water Management of the Tatar ASSR, and then the Deputy and Chairman of the Council of Ministers of the Republic, and before the collapse of the USSR, he became a member of the Central Committee of the Communist Party. In his speeches, he often addressed the nation as "Dear Tatarstan People". On March 25, 2010, on expiry of his term of office, he ceased to serve as President of the Republic of Tatarstan, becoming, as of April 1,2010, State Advisor to the new President of the Republic of Tatarstan, Rustam Minnikhanov.

18 The symbol of the Tatar-Russian history is the Kazan Kremlin, with the beautiful Qol-Şärif Mosque and the Annunciation Cathedral. Kazan is a very important city for the Orthodox Christians and the Russian identity, because of the cult of Our Lady of Kazan, which played an important role in the Russian history. 
and of coexistence of traditions and cultures" was approved by a vast majority of experts (Makarova, 2018) ${ }^{19}$ and inhabitants (Makarova, 2018) ${ }^{20}$.

The other concept - of the Tatar ethno-cultural nation - is advocated by the opposition ethno-political organizations, both the moderate ones, such as the All-Tatar Public Centre and the radical ones, such as the Ittifaq political party. They accuse the authorities of neglecting the interests of the Tatar nation. Its supporters believe that Tatars are an inseparable part of the "Turkic world", the ancient civilization that has been fostering Islamic spiritual values for a thousand years. Additionally, the Tatar national character demonstrates that they are an independent historical community within this family of nations. Contrary to Turkism and Islam, where Tatars are treated as a part of a larger (Muslim and Turkic) group, the Tatar nationalism sees the Tatars as a community of people who are aware of their unity and self-reliance (Mirsiiapov, 2004, p. 121).

Putting these concepts aside, Tatarstan launches initiatives to increase the political awareness of the Tatarstan nation through various forms of cultural nationalism expressed in everyday life. They also aim to strengthen the Tatars' sense of identity as a group separate from other nations, promoting the Tatar culture worldwide and making it equally known and popular as the Russian culture (Yusupova, 2018). These initiatives include three types of projects. The first group promotes the ethnic culture based on the Tatar literature, including the production of films and theatrical plays in the Tatar language and incorporating the Tatar history and ethnic music. Revitalization of the Tatar language is also pursued through discussions in social media. The second type of activity involves organizing public events connected with the local culture, such as festivals, ceremonies to mark important anniversaries and ethnic holidays, Tatar poetry reading events, and events to demonstrate solidarity with the Tatars in the region. The third type of initiatives promoting cultural nationalism in everyday life is of economic nature, including setting up gastronomic outlets serving Tatar cuisine, producing souvenirs, books, and games, and tourism to attract guests from other regions of Russia and from abroad (Yusupova, 2018).

The concepts of the nation in Chechnya were shaped differently than the ones in Tatarstan. The ethnically homogeneous population of Chechnya, its geographical, cultural, and religious conditions were conducive to ethno-cultural concepts based on shared origins, blood, and faith. However, the division of the Chechen population into family and tribal units and their tradition of living in an informal conglomerate, or network, of tribal connections

19 "In the period of Volga Bulgaria, the Golden Horde and the Khanate of Kazan, this was a region where various nations coexisted (...). And it is this combination that is reflected in many elements - the interweaving of cultures and traditions in material culture, Islamization and Christianization (...). Despite the difficulties, people found ways for peaceful coexistence, exchange and cultural integration".

20 Answering the question "Tatarstan - what is it like to you" and having a choice of two answers, the inhabitants of Tatarstan answered: stable $-33.3 \%$; multinational $-30.2 \%$; tolerant $-22.2 \%$; comfortable to live in, safe $-18.4 \%$. 
hindered building a strong state with a consolidated nation. After the USSR's collapse, several concepts of building statehood and nationhood emerged, seen mainly as a joint process, and their popularity wavered throughout the Russian-Chechen conflict. Along with the leadership changes, these concepts underwent various transformations and divisions.

The idea of a culturally Muslim state with a strong position of the president was advocated by Dudaev and later on by his successor and continuator, Aslan Maskhadov. He pressed for modernization of the state in line with the concept of "secular Islam", which would win him support from the Western superpowers and international organizations, and he also planned on limiting the role of family and tribal structures. President Maskhadov, on the other hand, probably as a tactical move, made some concessions to the commanding officers and their Salafic comrades ${ }^{21}$, which resulted in the loss of support among the Sufi clergy and the damage to his standing.

Shamil Basaev and Zelimkhan Iandarbiev advocated a different concept. They called for establishing an Islamic state together with other republics of the North Caucasus, with a legal order based on sharia law. To some extent, they shared the opinion of Dudaev and Maskhadov, who believed that a religious revival in the nation could lead to its retraditionalization. Mostly, however, they discerned the "de-Russianization" capacity of Islam and the resulting chance to rebuild the cultural identity of Chechens. This concept was even temporarily implemented when Z. Iandarbiev became president, as he immediately started introducing relevant changes in the republic's criminal code and the constitution ${ }^{22}$. This tendency grew more and more radical and reached its zenith with the leadership of Abdul Sadulaev, and later on - Dokka Umarov, when the independence ideas were abandoned and replaced to establish the Caucasus Emirate.

On the other end of the spectrum, there was the concept of a secular state loyal to the Russian Federation, supported by Doku Zavgayev, the first secretary of the local Soviet Communist Party, favored by Moscow but with no support from the society. Among the continuators of this idea was, among others, general Alkhanov, at one point the biggest rival to Ramzan Kadyrov. The Chechens - in line with their conservative national character pledged their support to the son of Akhmad Kadyrov (Sufi Chief Mufti), who was perfectly aware that only respecting the Chechen traditions and lifestyle would earn him the support of the majority of teips. The most influential group in Chechnya that has both power and support from the federal authorities is the Kadyrov clan, who - under the rule of Vladimir Putin - received more and more autonomy in internal affairs, which only strengthened the republic's isolation from the other parts of Russia. Islamization in Chechnya is growing increasingly, and the republic's law is now, to a large extent, based on adat and sharia law.

21 In 1999, Aslan Maskhadov issued a decree introducing a sharia court and sharia law on the Chechen territory.

22 In 1997, the Chechen Parliament introduced a law-making Islam the state religion, and also adopted the Sharia Penal Code, which was in fact the translated version of the 1983 Sudanese Sharia Penal Code. 
Due to the Chechen wars, the republic has almost entirely lost its Russian population, which results in its ethnicization. The political and administrative positions are held almost exclusively by Chechen nationals. Additionally, the teip-tukkhum model of society is upheld, demonstrated in the organization of regular conventions of all teips, the establishment of the council of elders, or recognition of collective responsibility in the local laws.

Another factor that impacted how the different models of ethnopolitics in both republics were shaped stems from the nature of Islam and how its politicization is manifested.

\section{Islam and Its Politicization}

Islam is an important component of the national identity of both Tatars and Chechens, and in both cases, it became the underlying element of their ethnopolitical mobilization. However, in comparison to other regions of Russia, the Islamic foundation of the ethnopolitical mobilization is in Tatarstan significantly limited due to its historical and ethno-cultural background, including the 400 years of Russian rule, a relatively high level of industrialization and secularization, and a large number of non-Muslim population, mainly Russians. It may also be the reason for the greater openness and tolerance of the 'Tatar' Islam, which developed under the Tatar and Russian cultures, contrary to the Caucasian Islam, shaped in isolation, in the high mountains.

The Tatarstan, in large post-Soviet authorities, brought up in the atheistic tradition, pursue an open religious policy. They underline the harmonious coexistence of the two most important religions - Islam and the Orthodox Church and emphasize the cooperation of religious organizations in tackling social matters, thus indicating their place in society. For the Tatar nationalists, Islam is a permanent and inseparable element of their national identity and crucial to its survival. Some nationalist activists, for instance, Rashat Safin, oppose pan-Islamism, arguing that Tatars should create their own version of Islam, and Tatarstan should become the intellectual center of the Islamic world in Eurasia. The official Islamic clergy, subordinated to the Muslim Spiritual Council of the Republic of Tatarstan, is loyal to the authorities. Also, the influence of the Islamic activists representing Salafism is weaker than in, for example, in the North Caucasus.

To a large extent, it became for the Chechens a tool for national integration and a component of their ethnic self-identification. Some researchers indicate even that behind the Muslim faith, there hides nationalism (Malashenko, Koppiters, \& Trenin, 1997, pp. 8-10). It is particularly important also at present, while we observe how the Caucasian republics culturally become more and more distant from the rest of the Russian Federation. The scarce Russian population in Chechnya does not favor cultural integration with the rest of the country and enhances the isolationist tendencies in the region.

Islam and adat also regulate the political life in Chechnya. Mosques serve not only as sacral sites, but they are also gatekeepers for public opinion and propaganda (both pro and anti-government, depending on their ideological affiliation). The rivalry between the 
official clergy - the circles that are loyal to the federal authorities and the Wahhabi clerics (Salafists) - has no negative impact on the growing re-Islamization of the Chechens. The federal authorities do not stop this process and even legitimize it, for instance, by putting the Republic's main mosques at the center of their visits to the republic.

The leaders and members of the Sufi communities play an important political role as well, and thus they also form the local elites (most of them are members of the Sufi wirds). Islam is also used for legitimizing the political leaders of the republic. Dzhokhar Dudayev came to power as the leader of one of the nationalist movements ${ }^{23}$, and one of the reasons he lost the legitimation of his power to Akhmat Kadyrov was that the latter was, first of all, a religious leader.

At some point, the Salafists had large support among the Chechen youth (during the Russian-Chechen wars, the soldiers were mainly young people). This popularity also resulted from the drop in the authority of the Sufi leaders who mainly (including Akhmat Kadyrov, father of Ramzan Kadyrov, the present Chechen leader) argued for ending the war for independence and stabilization of relations with the federal authorities. Now Islamic fundamentalists use modern technologies, such as the Internet, to promote their beliefs, which translates into their greater access to the younger generations of the Muslim republics in the Russian Federation and constitutes a challenge to the security service. Other centers of impact are also the educational institutions in the republic. They have extensive autonomy in preparing the curriculum, and they obtain funding from foreign non-governmental organizations from the Middle East. Next to Chechnya's infiltration by foreign missionaries, which started already in the 1990s and significantly contributed to how Caucasian Islam turned toward the radical Middle East model, educational institutions also became a convenient basis for intelligence activity of other Muslim countries. Islamic organizations are at times also a recruitment outlet for terrorist groups.

\section{Language Policy}

Language policy may be seen as a reflection of ethnopolitics since the language is related to the ethnic identity and plays an important role in its cultivation, manifestation, and development. Moreover, language policy affects the type of alphabet used, the spelling rules, vocabulary, and terminology. The nations in Russia, apart from Russians themselves, most often function as at least bilingual, using both the national and the Russian language, which stems from the federal structure of the state and the relevant laws. The language policy is shaped by the legislation but also by the historical and cultural conditions (the cultural and linguistic borderline areas) and the demographic potential of specific languages. Having particularly the two latter factors in mind, there is a discernible difference between the

23 The Naqshbandiyah members took his side and supported the Islamic radicals (Wahhabites) during the Russian-Chechen conflict. 
language policy in Tatarstan and Chechnya, mainly due to the actual status of the Tatar and Chechen languages.

The Tatar language is the official language in Tatarstan, next to Russian. However, the actual sphere of communication in Tatar is limited mainly to the rural environment, which has preserved its ethnic character. The Tatarstan towns mainly are Russian-language spheres. Russian and English were indicated as the language that is preferred and more useful at work, when dealing with the state administration, on the Internet, and even at home, including for respondents of Tatar origin. The function of the Tatar language is restricted only to the cultural sphere, and any initiatives to boost its popularity are mainly grassroots actions and not any official projects. Even migration from rural to urban areas does not increase the transmission of the Tatar language to the urban sphere of communication where Russian is dominant.

In September 1999, the republic adopted an act on the restoration of the Tatar alphabet based on the Latin graphic script. However, fearing that Tatarstan might become excessively independent, the federal authorities thwarted this process.

The ethno-linguistic processes in the republic have their own dynamics, also resulting from the demographic structure - the Tatar population has only a slight majority. In order to extend the use of the Tatar language, the authorities tried to make it obligatory as a school subject for all students. In response, the Russian Duma amended the act on education, making it obligatory to learn Russian while learning the national language, including Tatar, which is possible only if requested by the students' parents.

In distinction to Tatarstan, Chechnya is the sphere where communication in Russian becomes a problematic issue. At the turn of the 1980s and 1990s, in the period of the republic's sovereignization and ethnic mobilization, the prestige of the Chechen language increased. At the same time, the importance of Russian diminished as it became - in the eyes of the supporters of Chechen separatism - the language of the enemy (the Russian army) and the invader (the federal authorities in Moscow). The script of the language played a vital role as well - during the Russian-Chechen wars, the separatists tried to introduce the Latin alphabet, similarly as it happened later in Tatarstan. To this day is a growing number of schools, classes, and courses in the republic's educational institutions where students are taught in the native language, including in places where this never happened before.

As a result, while the older generations speak Russian very well, school-age children are not necessarily fluent users of Russian (Matsiev, 2007). Making the Chechen language the official language in the republic has practically made it impossible for other minorities to participate in public life (Guboglo, 1998, p. 84).

\section{Conclusions}

It should be noted that the analysis is not only intended to present Russian ethno-religious policy or strategies adopted by the government, depending on various conditions toward Muslim populations. From the perspective of the federation as a whole and the republic itself, 
the conciliation model of ethnopolitics used in Tatarstan turned out to be more effective and the realistic possibility for a republic located at the center of the continent. Tatarstan will remain a "Eurasian" republic, a place of the fusion of the Orthodox and Islamic civilizations. The republic, avoiding conflict, obtained special status as a federation subject integrated with the Russian state.

The model of resistance chosen by Chechnya seemed attractive and possible to implement due to the republic's external borders with other countries. Unfortunately, it turned out to be too radical and resulted in many victims and material losses. The local elites, led by the head of the republic, Ramzan Kadyrov, have pursued a policy of cultural sovereignty, as a result of which the cultural gap between Chechnya and the rest of Russia is widening. It can lead to another bloody conflict because the North Caucasus has a very important geopolitical significance for the Russian Federation, which will at all costs maintain loyal elites using the federal budget and will not allow the loss of control of that territory.

\section{References}

Avioutskii, V. (2005). Géopolitique du Caucase. Armand Colin.

Ben-Dior, G. (1988). Ethnopolitics and the Middle Eastern State. In M. J. Esman, \& I. Rabinovich (Eds.), Ethnicity, Pluralism and the State in the Middle East (p. 72). Cornell University Press.

Chandra, K. (2012). Introduction. In K. Chandra (Ed.). Constructivist Theories of Ethnic Politics (pp. 12-13). Oxford University Press.

Chuev, S. (2004). Prokliatye soldaty. Predateli na storone reicha. Eksmo.

Cordell, K., \& Wolff, S. (2004). Ethnopolitics in Contemporary Europe. In K. Cordell \& S. Wolff (Eds.), The Ethnopolitical Encyclopaedia of Europe (pp. 5-12). Palgrave Macmillan.

Galperin, Ch. (2003). Vymyshlennoe rodstvo. Moskoviia ne byla naslednitseĭ Zolotoř Ordy. Rodina, 12, 68-71.

Gdański, J. (2005).Zapomniani żołnierze Hitlera. De Facto.

Grochmalski, P. (1999). Czeczenia. Rys prawdziwy. Alta 2.

Guboglo, M. (1998). Iazyki etnicheskoi mobilizatsii. Studia Historica.

Hakim, R. (2003). Rus' tatarskaia. In Tatarskī put': prava naroda i politkorrektnost' (p. 35). Izdatel'stvo "Magarif".

Hakimov, R. (2005). Dva istoka rossiřskoĭ gosudarstvennosti. Rodina, 8, 45-47.

Karbainov, N. (2018). Ideologema 1552 goda v postsovetskom Tatarstanie: versiia èlit i massovye predstavleniia. In Power and elites. Vol. 5 (pp. 225-227). Sotsiologicheskii instytut RAN Federal'nogo nauchno-issledovatel'skogo sotsiologicheskogo tsentra Rossǐskoĭ akademii nauk.

Konstitutsiia Respubliki Tatarstan (v redaktsii zakonov Respubliki Tatarstan ot 19 aprelia 2002 goda № 1380, ot 15 sentiabria 2003 goda № 34-3RT, ot 12 marta 2004 goda № 10-3RT, ot 14 marta 2005 goda № 55-3RT, ot 30 marta 2010 goda № 10-3RT, ot 22 noiabria 2010 goda № 79-3RT, ot 22 iiunia 2012 goda № 40-3RT). (2020). http://minjust.tatarstan.ru/rus/konstitutsiya.htm?pub_id=1084014.htm Latypov, R. (2009). Mif o tatarskom natsionalizmie. Zhertvy Chingizkhana i Shaimmieva. https://apn-nn. com/analytic/mif-o-tatarskom-natsionalizme-zhertvy-chingizkhana-i-shaymieva- $/$ 
Makarova, G. (2018). Tatarstan v videnii èlit i prostyh zhiteleĭ republiki. The Journal of Sociology and Social Anthropology, XXI(2), 75-105.

Malashenko A., Koppiters B., \& Trenin D. (1997). 'Ruskiŭ natsionalizm i islam'. In Etnicheskiie i regionalnye konflikty w Evrazii, vol. 2 (pp. 8-10). Ves' mir.

Matsiev I. (2007). Iazykovaia dilemma Chechni. https://iwpr.net/ru/global-voices/\%D1\%8F\%D0\%B7\% D1\%8B\%D0\%BA\%D0\%BE\%D0\%B2\%D0\%B0\%D1\%8F-\%D0\%B4\%D0\%B8\%D0\%BB\%D0\%B5\%D0 \%BC\%D0\%BC\%D0\%B0-\%D1\%87\%D0\%B5\%D1\%87\%D0\%BD\%D0\%B8

Mirsiiapov I. (2004). Natsional'naia ideologiia i natsional'nye vzaimootnosheniia v Respublike Tatarstan. Izdatel'stvo Ves' Mir.

Model' Tatarstana - iskusstvo vozmozhnogo i nevozmozhnogo. (2000). http://shaimiev.tatarstan.ru/rus/ index.htm/ppub/1348062.htm

Osobennosti kavkazskogo mentaliteta i "novaia Rossiia”. (2011). http://test.vnatio.org/biblioteka/node84/ Rothschild, J. (1981). Ethnopolitics. A Conceptual Framework. Columbia University Press.

Sharafutdinova, G. (2000). Chechnya versus Tatarstan. Understanding Ethnopolitics in Post-Communist Russia. Problems of Post-Communism, 47(2), 13-22.

Trepavlov, V. (2003). Belyı̆ padishakh. Rodina, 12, 72-75.

Wierzbicki, A. (2011). Rosja. Etniczność i polityka. Oficyna Wydawnicza ASPRA-JR.

Wolosky, L.S. (2000). Putin's Plutocrat Problem. https://www.foreignaffairs.com/articles/russiafsu/2000-03-01/putins-plutocrat-problem

Yusupova, G. (2018). Cultural nationalism and everyday resistance in an illiberal nationalising state: ethnic minority nationalism in Russia. Nations and Nationalism, 24(3), 624-647. 